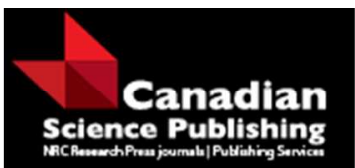

Canadian Journal of Forest Research

Revue canadienne de recherche forestière

\title{
Resident and cavity-nesting avian community is affected by amount but not age of white pine in central Ontario mature mixedwood forests
}

\begin{tabular}{|r|l|}
\hline Journal: & Canadian Journal of Forest Research \\
\hline Manuscript ID & cjfr-2015-0477.R1 \\
\hline Manuscript Type: & Article \\
\hline Date Submitted by the Author: & 29-Feb-2016 \\
\hline Complete List of Authors: & $\begin{array}{l}\text { Thompson, Ian; Canadian Forest Service } \\
\text { Wiebe, Philip; Canadian Forest Service } \\
\text { Kirk, David; Aquila Applied Ecologists }\end{array}$ \\
\hline Keyword: & old growth, cavity nesters, resident birds, white pine, selection harvesting \\
\hline
\end{tabular}

SCHOLARONE

Manuscripts 
Resident and cavity-nesting avian community is affected by amount but not age of white pine in central Ontario mature mixedwood forests

Ian D. Thompson, Canadian Forest Service, 1219 Queen St. east, Sault Ste. Marie, Ontario, Canada P6A 2E5 (ian.thompson@canada.ca)

Philip Wiebe, Canadian Forest Service, 1219 Queen St. east, Sault Ste. Marie, Ontario, Canada P6A 2E5 (philip.wiebe@canada.ca)

and

David. A. Kirk, Aquila Conservation and Environmental Consulting, Ottawa, Ontario, Canada (david.kirk1@sympatico.ca)

\section{Corresponding author:}

Ian Thompson

Canadian Forest Service,

1219 Queen St. east, Sault Ste. Marie, Ontario, Canada P6A 2E5

Email: ian.thompson@canada.ca

Tel: 7055415644

Fax: 7055415700 


\section{Abstract}

2 Forests with old growth white pines have been severely reduced compared to historical levels.

3 We examined resident and cavity-nesting bird species abundances in winter and the breeding

4 season because some of these species may prefer old forest habitats for breeding. We counted

5 birds over 10 years in four mixedwood types: old pine, mature pine, mature non-pine, and

6 selection-harvested stands. We expected that old pine stands would be selected by some

7 species because of abundant snags and large trees for foraging. We assessed habitat use

8 among years, and changes following harvesting. Counts of nomadic species varied across years

9 but counts for others did not. Species used old and mature pine mixedwoods equally and more

10 than non-pine or harvested stands in winter and for breeding, but old stands were not

11 preferred. Important variables included percent pine and large tree density. Selection

12 harvesting benefitted yellow-bellied sapsuckers but reduced counts of black-capped chickadees

13 and brown creepers. Black-capped chickadees changed habitats between seasons and in some

14 years. Black-backed woodpeckers were most common in pine stands but abundant in

15 harvested stands for 2 years following cutting. Regardless of stand age, large $(>40 \mathrm{~cm})$ pines

16 provide important habitat for residents and cavity-nesters.

17

18 Keywords: old growth, cavity nesters, resident birds, white pine, selection harvesting.

\section{Introduction}

21 Loss of primary forests is a global concern as a result of unsustainable use in many

22 areas, because of the long time period for forest recovery, stand degradation, and uncertainty 
23 over the quality of second-growth forests to sustain the original biodiversity (Thomas et al.

24 1988, Mosseler et al. 2003, Blaser et al. 2012). In eastern Canada, long-lived tree species,

25 including white pine (Pinus strobus) and red pine ( $P$. resinosa), occur in the Great Lakes-St.

26 Lawrence forest type and the most southern parts of the boreal forest (Rowe 1972). These pine

27 forests, in pure or mixedwoods with 30 to $80 \%$ pine by basal area, have been logged for

28 centuries, starting early in the 1600 s for wooden ships and continuing until the present for

29 sawn wood (Aird 1985, Wray 1986). This long history of pine logging, coupled with fire

30 suppression, which reduces the rate of natural regeneration (Carleton 2003), has resulted in

31 only a few remaining fragmented primary old-growth pine forest stands and the loss of this

32 forest type over much of the region (Thompson et al. 2006, Venier et al. 2014).

33 The vast reductions of old growth pines, from pure and mixedwood stands in Ontario

34 has led to concerns about the distinct biodiversity that might be supported in these forests

35 (Welsh et al. 1992, Venier et al. 2014). In an earlier study, Kirk et al. (2012) assessed the value

36 of mature and old red pine and white pine mixedwood forests in Ontario as avian habitats and

37 found that age and size (diameter) of pine in these stands contributed to breeding habitat

38 selection by several species. They derived models implicating old growth conditions as

39 important for some resident and cavity-nesting species including brown creeper, red-breasted

40 nuthatch, and pileated woodpecker (see Appendix 1 for scientific names). These species use

41 cavities or dead trees to nest, and the pileated woodpecker is a management indicator species

42 in Great Lakes-St. Lawrence Forest type in Ontario (Ontario MNRF 2015). Brown creeper and

43 boreal chickadee are species that have been suggested as old forest specialists in several

44 studies, both in mixed transition forests (Poulin et al. 2008) and in the boreal forest to the north 
45 (Drapeau et al. 2000, Thompson et al. 2014). Hence, these species may be declining with the

46 loss of old-growth forest habitats (Venier et al. 2014). An important structure that is usually

47 more abundant in old growth than mature forests is snags (Smirnova et al. 2008, Vaillancourt et

48 al. 2008), which are important for roosting, feeding, and breeding by cavity nesters and many

49 resident species (Hejl et al. 2002, Lemaitre and Villard 2003, Poulin et al. 2008, Straus et al.

50 2011). Similarly, very large live trees, such as white pine and red pine, in old growth forests

51 provide a foraging resource for many avian species (Connor 1981, Weikel and Hayes 1999).

Here, we build on the earlier work of Kirk et al. (2012), with a study during an 11-year

53 period, to assess the importance of old pine mixedwood stands specifically for resident birds

54 and the non-resident cavity-nesters on an annual basis, in spring for breeding and over winter

55 for food and shelter. For the resident birds, individual fitness is affected by the quality of over-

56 wintering habitats where they have to survive harsh winter conditions, as well as by the quality

57 of spring breeding habitats (Desrochers et al. 1988, Straus et al. 2011). We asked the following

58 five questions: 1 .) does age of pine and amount of pine in a stand affect resident and cavity-

59 nesting species habitat selection in spring and in winter for residents? We asked this question

60 because of the preference of forest managers to cut white and red pines before the old growth

61 stage. Our hypothesis was that old growth stands would have more snags and more large trees

62 than mature stands, and so should be more important to breeding birds and winter foraging

63 than stands without large pines (Flemming et al. 1999, Harestad and Keisker 1999, Nappi et al.

64 2015). 2.) Are winter densities equivalent among years, or are there some years in which old

65 growth pine or other stands are especially important to some species? For the latter question,

66 we expected that nomadic (irruptive) species that feed on mast, such as pine siskins, crossbills, 
67 and pine grosbeaks, might invade stands with a high density of pines during years with

68 abundant mast (Koenig and Knops 2001). 3.) Based on differing responses of bird species to

69 selection harvesting (Gram et al. 2003, Poulin et al. 2010), we assessed whether or not selection

70 harvesting for large pines would reduce the nesting density of cavity-nesting species. Finally,

71 with respect to inter-annual bird abundances and species composition, we asked two

72 questions. First, 4.) does winter abundance predict spring breeding density of resident species?

73 This question is of interest because of the potential for censusing indicator species in winter,

74 rather than during spring breeding. Several authors have noted differences in foraging

75 behaviours and habitat preferences between summer and winter for various resident species

76 (Kilham 1965, Connor 1981, Gow et al. 2013) and dissimilarity in seasonal habitat use has

77 management implications. Our last questions was 5.) does habitat selection vary within species

78 across years? Most avian studies are conducted over a much shorter term and so cannot

79 address this question of change in habitat use that may occur as a result of changes in

80 resources (e.g., food) among years.

82 Methods

84 Study area

85 Our study area was located in the Lower Spanish Forest Management Unit, north of

86 Espanola and west of Sudbury, Ontario, in an area of transition between southern temperate

87 mixedwood forests and the northern boreal zone. We selected the area because it still

88 maintained large stands of old growth (>120 yrs) and mature (90-120 yrs) white pine and red 
89 pine mixedwoods in forest reserves. The topography was hilly and rough with frequent rock

90 outcrops and cliffs, surrounding numerous large lakes, and underlain by coarse glacial tills.

91 Winter temperatures were below $-40 \mathrm{C}$ for extended periods and summer temperatures rose to

92 near 35 C. Colder winters were common when the study began in 1995 but less cold winters

93 generally prevailed after 1998. We conducted our winter study from spring 1995 to 2005, with

94 no data collection in winter 1999-2000 because the main access road was not ploughed. We

95 sampled breeding birds in spring from 1999-2007.

We sampled forest stands in four types of mixedwoods, where pine ranged from 30 to

$9780 \%$ of the basal area: old growth pine $(n=6)$, mature pine $(n=7, n=6$ after 2003$)$, mature

98 non-pine $(80-120 \mathrm{yrs}$, with $<20 \%$ basal area in pine) $(n=4)$, and selection-logged former pine

99 dominated stands ( $n=4, n=5$ after 2003). Of the latter stands, we could only sample two in

100 winter (3 after 2003) and so these data were not used in analyses. Dominant deciduous species

101 were trembling aspen (Populus tremuloides), white birch (Betula papyrifera), and sugar maple

102 (Acer saccharum), with some yellow birch (B. alleghaniensis). Dominant conifers, other than

103 pines, were black spruce (Picea mariana), white spruce ( . glauca), and balsam fir (Abies

104 balsamea). The selection-harvested stands were logged primarily for large pines in the first

105 year of the study, with one or two pines/ha left as seed trees These four stands were the only

106 ones available on the study area. A mature pine stand was selection-logged in 2003 and so

107 changed type, and increased our sample of harvested stands to 5 for the last 4 years of summer

108 study.

109

110 Data collection 


\section{Avian sampling}

112 We censused birds in winter (January or February) and in spring (May to late June).

113 Most of the same stands/plots were used in many years but some could not be censused in all

114 years owing to impassible winter access. Regardless, our sample was a minimum of five plots

115 for all unmanaged stand types. For winter surveys, one fixed square $0.49 \mathrm{~km}^{2}$ plot $(700 \times 700$

$116 \mathrm{~m}$ ) was established in each stand, located $100 \mathrm{~m}$ from an edge or other stand type on all sides.

117 In summer, we used a smaller $0.25 \mathrm{~km}$ plot $(500 \times 500 \mathrm{~m})$ that was centred within the winter 118 plot.

119 In winter, we sampled birds on four parallel transects $175 \mathrm{~m}$ apart and along the joining

120 lines between the long transects, which covered the entire plot such that no part of the plot

121 was more than $87 \mathrm{~m}$ from an observer. A single observer walked slowly along the transects,

122 stopping frequently and recording all birds seen or heard, including those flying over the plot.

123 Quiet 'pishing' was used in winter, if necessary, to draw already-detected birds to the observer

124 for identification. Time on plot varied among observers and plots, ranging from 2.5 to $3.5 \mathrm{hrs}$,

125 mostly owing to terrain differences on the plots. We censused two plots per day, after testing

126 results from six plots showed that the number and species of birds detected in the morning and

127 afternoon did not differ. Winter surveys were done during late January and early February, and

128 late February to early March. In the last several years of the study, we could only make one

129 winter trip and the late period was selected for the census.

130 In spring, surveys were done from mid-May until late June. We used call playbacks to

131 census woodpeckers (e.g., Hoyt and Hannon 2002) with a mixture of calls and drumming of

132 each species was played, individually in a sequence of 1 minute followed by 3 minutes of 
133 silence, three times at each station. There were nine stations on each plot, such that no point

134 on the plot was located more than $50 \mathrm{~m}$ from a playback station. We adjusted the volume of all

135 playback cassette player and speaker combinations so that we could hear the calls faintly at 50

$136 \mathrm{~m}$. Resident species (other than woodpeckers) were recorded when seen or heard

137 singing/calling at each listening station during the playback period and during an additional 5-

138 min listening period after the playbacks, for an unlimited distance (Welsh 1995). Spring plots

139 were only censused in mornings until 10:30 hrs.

140 In spring and winter, we used plot maps to aid in determining if a bird may have been

141 detected more than once, by mapping the approximate location when first heard and any

142 subsequent movements by the bird, and all obvious duplicates were only counted once. Plots

143 were not censused if the wind exceeded $20 \mathrm{kmh}$, or on days when it was snowing heavily or

144 raining. Plot surveys were discontinued if winds came up during the census and the plot was

145 re-started on another day.

$146 \quad$ Vegetation sampling

147 Stands were surveyed for tree $(>10 \mathrm{~cm} \mathrm{dbh})$, small tree $(<10 \mathrm{~cm} \mathrm{dbh,}>3 \mathrm{~m}$ tall), snag

148 (dead tree), and shrub (<3 m tall) densities, heights, diameters, and species composition.

149 Woody vegetation data were collected systematically at 50 or 100 points per stand, depending

150 on variance after 50 points, 20 to $30 \mathrm{~m}$ apart along random transects across the entire stand,

151 using the point-distance technique of Batcheler (1975). Stand basal area was determined by

152 multiplying stem density by the average diameter for each species and then summed. The

153 point-distance method corresponds well to values for basal area determined using standard 
154 forest inventory prism plots (Thompson et al. 2006). The age of each stand and species was

155 taken from government forest resource inventory maps.

156 Cavity searches

157 In spring of each year, we searched two to four plots of each forest type to determine

158 the number of cavities present and to attempt to locate nests. Four observers walked parallel

159 lines a few metres apart, examining all trees on the plots for possible cavities. Cavities

160 accessible either by climbing or using a $4 \mathrm{~m}$ ladder were all examined. Cavities larger than $2 \mathrm{~cm}$

161 and lower than $16 \mathrm{~m}$ were examined with a remote camera mounted on a telescoping pole.

162 Cavities located above $16 \mathrm{~m}$ could only be estimated, by using binoculars, as either nesting or

163 feeding, unless birds were seen using the hole. We recognize the inherent difficulties with

164 finding cavities (Harper et al. 2004, Ouellet-Lapointe et al. 2012) and that cavities above $16 \mathrm{~m}$

165 were likely overestimated as useable, although few cavities were above that height.

166

167 Treatment and analysis of data

168 Avian detections were linearly related to time on winter plots $\left(r^{2}=0.55, P<0.01\right)$, so we

169 first standardized census data by using the catch-per-unit-effort (CPUE) method to adjust each

170 plot count of birds to 3 hours sampling duration. For the years 1995-1998, two visits were

171 made in winter to sites, whereas for other years (1999-2005) only one visit was made in

172 February. To rectify this uneven sampling effort, we randomly selected one of the two visits

173 from 1995-1998. (Taking the maximum or mean count of the two visits could have biased the

174 counts for the sites that were visited twice.) 
We created separate data matrices for the winter and spring bird data, and a separate

176 dataset with matched winter and spring plots for those species that occurred in both seasons.

177 The spring data were the number of birds of each species, with territorial individuals counted as

178 two and possibly unmated birds counted as an individual. We combined these counts to make

179 them equivalent to counts of birds done during the winter period, adjusted to plot size. We

180 pooled bird species into functional groups based on their cavity-use and residency status (see

181 Appendix 1). We calculated Simpson's diversity index individually for all sites.

$183 \quad$ Statistical analyses

184 Winter and spring data were analysed separately. For single species, functional groups,

185 nomads, and the Simpson's diversity index, we used generalized linear mixed models (GLMM)

186 to determine the importance of habitat characteristics on abundance and diversity. Abundance

187 of single species, pooled abundance for functional groups and Simpson's Diversity Index were

188 used separately as response variables and stand structural variables and year as predictors. For

189 Simpson's index, we used Box-Cox normality plots to determine the best power

190 transformations based on a Gaussian error family. For all of the other response variables,

191 which were count data, we used a Poisson error family with log-link. For all models, we

192 included year as a random factor to account for repeated measures because of possible

193 temporal autocorrelation, as our surveys were conducted at the same sites for 10 years.

194 Small sample sizes of each forest type limited the number of variables that could be

195 included in each regression model, so we chose to use model averaging for parameter

196 estimation according to methods recommended by Burnham and Anderson (2002), and AICC 
197 (Akaike's Information Criteria, corrected for small sample size) as the selection criterion. From

198 global models that included stand type, percent pine in the stand, basal area of the stand, and

199 density of snags in the stand as fixed effects, we compared all subsets that included three or

200 fewer variables. Parameter estimates were averaged over all models included in the $95 \%$

201 confidence set that included each variable. Conditional averages were reported instead of full-

202 model averages because not all variables had the opportunity to be included in all models. The

203 importance of each variable was calculated by summing the AICC weights of all of the models in

204 the $95 \%$ confidence set that included that variable.

205 For each instance where the model-averaged stand type parameter estimates indicated

206 that there were significant differences among levels, post-hoc multiple comparison tests were

207 conducted on a GLMM model that included each of the variables that had $95 \%$ confidence

208 intervals that did not include 0 to determine where differences existed. Tukey's method was

209 used to adjust the confidence limits based on the number of tests conducted.

210 We used GLMMs to test for differences in the proportion of birds in particular stand

211 types between winter and spring census periods. Odds ratios were used as response variables

212 consisting of counts of each bird species within plots compared with the total number of birds

213 of the same species in all other plots from the same census season. A binomial family of errors

214 was used with a logit link. Stand type nested within year were designated as random factors to

215 pair similar stands within years and account for the repeated measures. We designated year as

216 a random effect and where season and stand type plus an interaction term were fixed effects.

217 A significant interaction or difference by season would indicate differences in proportion of

218 species within a particular stand type between seasons. To test for differences between winter 
219 and spring counts, we used counts for the 6 years for which we able to sample in both winter

220 and spring in the same year.

221 For species that were known to nest in snags, we used general additive model (GAM)

222 plots and GLMM models to test for non-linear relationships with snag density that might

223 indicate thresholds up to which snag density might be a limiting resource. If snag density was

224 limiting, but only up to a certain level, then we expected to observe significant curve

225 parameters using quadratic terms for snag density that indicated a hump-shaped relationship

226 peaking at intermediate snag densities, but not decreasing substantially at the high end of

227 values measured. Snag densities within stands were positively skewed and were transformed

228 to improve model performance. Box-Cox normality plots indicated the best power

229 transformation was -1 (inversion). Nesting season counts were used with weak cavity nesters,

230 black-capped chickadees, red-breasted nuthatches, and brown creepers.

231 To test for differences in habitat selection among years, we constructed GLM or GLMM

232 models that included species counts as the response, stand type as an explanatory variable, and

233 three different forms of year as explanatory variables. For each species that contained at least

234100 observations across all years for a season, plus brown creepers, we compared three models

235 using AICc and calculated the Akaike weight for each: year as a random intercept, year as a

236 fixed intercept, and year as a fixed intercept plus an interaction with stand type. If the AICc

237 comparison indicated that the latter model was the most parsimonious, then we accepted this

238 as evidence for differences in habitat selection among years.

239 We examined generalized linear mixed models (GLMM) in the R-statistical package

240 (version 3.2.0; R Core Team 2015), using package Ime4 (version 1.1-8; Bates et al. 2015). Multi- 
241 model inference and parameter estimation was conducted using package MuMIn (version

242 1.15.1; Barton 2015). Multiple comparison tests were conducted using the multcomp package

243 (version 1.4-0; Hothorn, Bretz and Westfall 2008). For GAM model plotting, we used the mgcv

244 package (Wood 2011).

246 Results

Avian species composition and abundance

The most common resident birds recorded in winter, totalled for the 11 years, in rank

250 order were: black-capped chickadee, red-breasted nuthatch, downy woodpecker, common

251 redpoll, and white-winged crossbill (Figures 1 and 2, Appendix 2). In spring, the rank order of

252 the most common resident and/or cavity-nesting species was black-capped chickadee, red-

253 breasted nuthatch, and downy woodpecker (Figures 3 and 4, Appendix 3). White-winged

254 crossbills and pine siskins, while common in winter, were irruptive and rarely present in the

255 spring. We recorded 17 other resident species (total resident species $=22$ ) although some,

256 such as three-toed woodpecker, were seldom seen. Among the migrant cavity-nesting species,

257 yellow-bellied sapsucker was the most abundant species (total cavity-nesting species = 9),

258 surpassing all other species in abundance for all stand types in most years.

There were no differences in the abundances of common species among years for either

260 season (Ps $>0.05$ ), although numbers fluctuated considerably (Figures 1 to 4). Among the

261 winter nomadic bird species, white-winged crossbills were only abundant from 2003 to 2005,

262 occurring mostly in old and mature pine stands, compared to a very few individuals in most 
263 other years or stand types (Figure 2). Other irruptive species included pine siskins that were

264 common in 2003 , common redpolls that were abundant only in 2001 , red crossbills that were

265 most common in 1997 but absent after that, and pine grosbeaks that were relatively abundant

266 in 2003 but with few individuals recorded in only two other years.

268 Stand variables

269 We found no difference in the mean number of snags/ha among the four stand types,

270 which within stand types ranged from $16.2 \pm 3.2$ to $48.1 \pm 3.1 /$ ha. There was a significantly lower

271 tree basal area in the selection logged stands $\left(9.4 \pm 1.8 \mathrm{~m}^{2} / \mathrm{ha}\right)$ than in the other stand types $(P<$

2720.001 ), where the basal areas did not differ (stand range $17.0 \pm 0.9$ to $20.0 \pm 1.2 \mathrm{~m}^{2} / \mathrm{ha}$ ). The

273 basal area of large trees $(>40 \mathrm{~cm})$ was the same in old and mature pine types (10.4 and 8.9

$274 \mathrm{~m}^{2} /$ ha, respectively) but significantly higher than in the non-pine mixedwoods $\left(1.0 \mathrm{~m}^{2} / \mathrm{ha}\right)$ and

275 the selection harvested stands $\left(2.2 \mathrm{~m}^{2} / \mathrm{ha}\right)(P<0.001)$. Large tree density was correlated to

276 total tree basal area in the stand. Our pine stands varied in amount of pine from 30 to $84 \%$ of

277 the tree basal area, with significantly more pine in the two pine types than the other two stand

278 types $(P<0.001)$.

279

280 Stand variables influencing winter bird species abundance and composition

281 In winter, stand type was important for weak cavity excavators, residents, and for six

282 among 14 species, excluding ravens (Table 1). Species richness was the same for all three stand

283 types. For those species with models implicating stand type as significant, mature and old

284 growth pine was used most by weak cavity excavators, residents, back-capped chickadee, red- 
285 breasted nuthatch, and pine siskin (Table 2). Old growth pine was not the most used type for

286 any group or species. Percent pine was a significant variable for residents, nomads, and four

287 species (but negative for boreal chickadee). Tree basal area was significant for weak cavity

288 excavators, residents, and six species (negative for pine siskin, black-backed woodpecker, and

289 pine grosbeak). Number of snags/ha had a negative effect for overall species richness, weak

290 cavity excavators, residents, and black-capped chickadee, and was positive for pine siskin, an

291 irruptive species in our area.

292

293 Stand variables influencing breeding cavity-nesting bird species composition and abundance

294 In the breeding season, stand type influenced the strong excavator guild, non-residents,

295 and six of the nine common breeding species (Table 3), but none of those species preferred old

296 growth pine stands (Table 2). Species composition did not differ among the four stand types.

297 Black-capped chickadee and brown creeper used harvested stands least and brown creepers

298 were most common in old and mature pine mixedwoods (Table 2). Strong cavity excavators

299 preferred selection harvested stands, where we recorded the highest counts of yellow-bellied

300 sapsuckers (Figure 3). Percent pine was positively related to abundance in models for black-

301 backed woodpecker and brown creeper and was negative for yellow-bellied sapsuckers.

302 Selection harvesting reduced stand use significantly by black-capped chickadee and brown

303 creeper. Stand basal area (or its correlate large trees) was important for weak cavity

304 excavators. Snags was positive for yellow-bellied sapsuckers, slightly negative for pileated

305 woodpeckers, but had no effect in models for any of the weak cavity excavators (Table 3). We 
306 also tested subsets of snags in small $(10-19 \mathrm{~cm} \mathrm{dbh})$ and large size $(\geq 20 \mathrm{~cm} \mathrm{dbh})$ classes in our

307 models but found the same non-effect.

308 In a post-hoc fashion, we tested the relationship between numbers of snags and

309 numbers of breeding birds of each species to determine if the number of snags might be so

310 numerous as not to limit breeding sites. We saw no relationship between the number of snags

311 and bird abundance for red-breasted nuthatches, from the GAM plots and polynomial GLMM

312 models. For brown creeper, we observed an inflection point at 20 snags/ha $(P<0.06)$ and for

313 black-capped chickadee there was a clear inflection point at 14 snags/ha $(P<0.04)$.

314 Selection harvesting had no effect on species richness and six of our nine breeding

315 species, a positive effect for two woodpeckers, and a negative effect on brown creeper and

316 black-capped chickadee (Table 2). Although we observed low variance among years for

317 breeding cavity-nesting species, we noted a significant decline in the number of black-backed

318 woodpeckers breeding in our selection harvested stands in the third year after the stands had

319 been harvested (Figure $3, z=2.61, P<0.01$ ). Further, the number of black-backed

320 woodpeckers breeding in harvested stands was significantly higher than in all other stand types

321 for the first 2 years post-harvest, after which counts then declined to levels similar to those in

322 the other stands $(z=2.76, P<0.01)$.

324 Nest sites

325 We documented 47 nest sites of eight cavity-nesting species on or near our plots. Of

326 these nests, $68 \%$ were in trembling aspen, and $62 \%$ were in live trees and $38 \%$ were in snags.

327 Most nests that we located were of red-breasted nuthatch (11; 9 in snags) and yellow-bellied 
328 sapsucker (18; 15 in live trees). Aspen used by small woodpeckers $(n=21)$ had a mean $d b h$ of

$32933.5 \mathrm{~cm}$, while pileated woodpeckers $(n=3)$ used larger aspen with a mean diameter of $53 \mathrm{~cm}$,

330 all of which were in old growth stands. We found four nests in large diameter declining old

331 white pine, three of which were common flickers. For the weak cavity excavators, 10 of 12

332 nests were in snags (9 red-breasted nuthatch and 1 black-capped chickadee).

334 Abundance of resident birds in winter relative to spring

335 With the exception of black-capped chickadees and black-backed woodpeckers in

336 mature pine, abundances in winter did not differ from breeding counts in spring (Ps $>0.05)$.

337 Numbers of black-capped chickadees did not differ in old pine or non-pine mixedwoods, but

338 counts in mature pine were significantly higher in winter than in spring $(P<0.01)$. Therefore,

339 for most species, winter counts predicted the numbers of spring breeders. Counts in selection

340 harvested stands in winter were high by inspection, but the sample was insufficient to test.

342 Relative abundances of bird species within habitat types over 10 years

$343 \quad$ For spring breeding birds, no models with an interaction between stand type and year

344 were more parsimonious than models without an interaction, indicating that the relative

345 abundances among stand types did not change for any species over the 10 years of study (Table

346 4). The result was the same for all species in winter, except for black-capped chickadees that

347 differed in relative abundances among stand types in some winters (Table 4).

349 Discussion 
351 for any resident or cavity-nesting species, for breeding or over-wintering. No species selected

352 white pine/red pine mixedwood stands more than the non-pine mixedwood types for breeding

353 and old growth pine and mature pine mixedwoods had similar importance levels in all cases, in

354 either spring or winter. In winter, old pine stands were not used more by resident birds than

355 either mature pine or non-pine, depending on the species or group. Part of the reason for that

356 result may have been that old growth and the other forest types maintained similar numbers of

357 snags, and that the numbers of large trees in both pine age classes was also similar. The

358 amount of pine in the stands, however, was a significant positive variable for several species

359 and guilds, both for breeding and over-wintering, as also found by Kirk et al. (2012).

360 Amount of pine, and large pines in particular, may have provided good foraging

361 substrates for many wintering birds, especially for residents as a guild, and white-winged

362 crossbills that were a common nomadic species. Connor (1981) observed an increase in

363 foraging on pines in winter by downy and hairy woodpeckers, and pileated woodpeckers are

364 well-known to seek carpenter ant galleries in old and mature pine trees (Lemaitre and Villard

365 2005). Brown creepers forage on large trees with deeply furrowed bark and red-breasted

366 nuthatches also prefer large trees for foraging (Weikel and Hayes 1999, Farris et al. 2010).

367 Large trees support more arthropods, including eggs and larvae than smaller trees (Mariani and

368 Manuwal 1990, Farris et al. 2010) and mature and older white and red pines, with their deeply

369 furrowed bark, likely provided this resource in our area. Percent pine in a stand was also

370 important to white-winged crossbills although they did not favour pine stands and to pine

371 siskins that used pine stands more than non-pine stands; both latter species are well-known to 
372 forage on pine seeds (Koenig and Knops 2001). Total abundance of nomads did not, however,

373 vary among stand types and this may have been because the other abundant nomadic species,

374 common redpolls, feed mostly on seeds of deciduous species (Martin et al. 1951, Kennard

375 1976). Black-capped chickadees forage for insects on many tree and shrub species, often

376 favouring deciduous trees (Holmes and Robinson 1981, Hill and Lien 1988, Gayk and Lindsay

377 2012), but also feed on mast. Black-capped chickadees preferred pine mixedwoods in the

378 winter possibly for both mast from pines and foraging resources on the deciduous component.

379 Our data indicated that resident birds do not distinguish between old growth and mature pine

380 stands but the presence of large pine trees (correlated to basal area in our models) was likely a

381 key foraging habitat for many resident species.

382 Pine was important for two species during the breeding season. For breeding black-

383 backed woodpeckers, the importance of pine was probably related to foraging opportunities on

384 the several species of bark beetles (Scolytidae) that are associated with both red and white

385 pines in eastern North America (Rose and Lindquist 1984). Black-backed woodpeckers forage

386 preferentially on large conifer trees in old forests (Villard 1994, Tremblay et al. 2009, Nappi et

387 al. 2015). Similarly, brown creepers forage for arthropods preferentially on large conifer trees

388 with rough bark, such as old pines, at all times of the year (Franzreb 1985, Adams and Morrison

389 1993, Poulin et al. 2008). Poulin et al. (2008) suggested a threshold of 127 large trees/ha (>30

$390 \mathrm{~cm})$, above which brown creepers were likely to nest in old forests in New Brunswick. On our

391 area, mature and old pine stands had an average of more than 228 trees/ha $>30 \mathrm{~cm}$, but our

392 non-pine mixedwoods that were used equally by brown creepers had a mean of 94 large

393 trees/ha. On the other hand, selection harvested stands, with significantly fewer brown 
394 creepers, had only 64 large trees/ha. This would suggest that brown creepers in eastern

395 transition mixedwoods may need as few as 94 large trees/ha for breeding, somewhat less than

396 was required in New Brunswick. In our mixedwood forests, brown creepers may have required

397 fewer large trees than was suggested in New Brunswick because many of largest trees on our

398 study area exceeded $40 \mathrm{~cm}$ dbh providing a much greater foraging surface than a $30 \mathrm{~cm}$ tree.

399 Kirk et al. (2012) showed a 33\% probability of occurrence of brown creepers with 62 stems/ha

400 of medium and large pines. Thresholds are of direct management interest because they enable

401 direction for key variables for planning.

402 Snags provide another important foraging and nesting substrate for residents and

403 woodpeckers (e.g., Kisiel 1972, Lemaître and Villard 2005, Nappi et al. 2015) and so the lack of a

404 difference in snag density among our stand types could partly explain the similar use that we

405 observed for many species. Although less use is made of snags for nesting by woodpeckers

406 than live trees in general (Peck and James 1983, Tozer et al. 2011), snags are used by some

407 woodpeckers to nest and by weak-cavity excavators (Harestad and Keisker 1988, Hejl et al.

408 2002). For weak cavity excavators, the lack of a relationship between numbers of snags and

409 breeding pairs was unexpected because these species usually nest in dead trees, or under the

410 bark of dead trees in the case of brown creepers (Davis 1978). Our data for red-breasted

411 nuthatch also indicated a preference for nesting in snags and the lone black-capped chickadee

412 nest that we found was in a small broken dead white birch stem. Some authors have also found

413 no correlation between breeding cavity nesters and snag or hole density (Waters et al. 1990,

414 Carleson et al. 1998, Spiering and Knight 2005), while others have reported nest site limitation

415 for cavity nesters (Brush 1983, Miller 2010). We found no relationship in our models between 
416 breeding density and snags for any species but we did find evidence of a threshold for snags for

417 two of the three weak cavity excavator species tested. Elsewhere, Guenette and Villard (2005)

418 and Poulin et al. (2008) suggested that a threshold for occurrence and breeding of brown

419 creepers was about 56 snags/ha in New Brunswick substantially higher the value of 20/ha that

420 our data suggested. Their Atlantic forests were largely balsam fir and black spruce that we

421 suspect provided much lower quality nesting snags than pine mixedwoods. The characteristic

422 thick bark of pines hangs in sheets on dead trees for several years providing nesting cover

423 unlike the thin bark of balsam fir that provides little cover. As a result, more snags are likely

424 necessary in New Brunswick spruce-fir forests, than in our mixedwoods, to ensure sufficient

425 snag quality for nesting brown creepers. Tremblay et al. (2015) suggested that black-backed

426 woodpeckers would use stands with 200 snags/ha in boreal forests, which was about four to

427 five times more than occurred in any of our stands and yet this species nested in comparable

428 density in our forests. The latter comparisons for a snag thresholds between regional forest

429 types, similar to the comparison above for large trees, clearly shows that thresholds for specific

430 variables influencing species' life histories need to be developed independently for different

431 forest ecosystems.

432 From the few published records, woodpeckers use larger trees than the stand mean

$433 \mathrm{dbh}$ for nesting, although the reported required sizes vary among those few studies. In boreal

434 and transition forests of eastern North America, trees with a dbh >20-33 are common for

435 nesting by small woodpeckers (Peck and James 1983, Ouellet-Lapointe et al. 2012, Tremblay et

436 al. 2015), while pileated woodpeckers nest in trees with a dbh $>35 \mathrm{~cm}$ (Peck and James 1983,

437 Towers et al. 1992). Our nest tree diameter data were similar to these values. Regardless, 
438 there is surprisingly little available information on tree sizes selected for most nesting by cavity-

439 nesting bird species in eastern temperate and transition forests.

$440 \quad$ Selection harvesting has previously been found to have negative effects on some cavity-

441 nesting species through the removal of large trees and the loss of snags (Poulin et al. 2010,

442 Tozer et al. 2010, Straus et al. 2011), and positive or neutral effects for other species (Mancuzzo

443 et al. 2008, Tozer et al. 2010, Straus et al. 2011). Our results also indicated positive, neutral,

444 and negative effects depending on the species. For brown creepers, loss of large foraging trees

445 and appropriate nesting snags was likely responsible for the observed decline in logged stands.

446 Poulin et al. (2010) attributed a decline of brown creepers in partially harvested New Brunswick

447 forests to foraging opportunity limitation as well. Yellow-bellied sapsuckers responded

448 positively to selection harvesting, where they nested almost exclusively in large remaining

449 aspens. Impacts of selection harvesting on sapsuckers has had different effects: in

450 southwestern Ontario, lower densities of this species occurred following partial harvesting,

451 while Mancuso et al. (2014) found little effect on breeding density in eastern Ontario. We did

452 not follow the success of individual nests but Tozer et al. (2009) reported lower nesting success

453 by sapsuckers in open stands following partial harvesting, suggesting that density alone may

454 not be a good indicator of fitness.

455 Black-backed woodpeckers generally occur in old forests in low densities but are

456 attracted to burned areas with their short-term abundant food resources (Hannon and Drapeau

457 2005). We found that black-backed woodpeckers increased their use of selection harvested

458 stands for at least 2 years following harvesting to densities exceeding those in our uncut forests

459 and equivalent to counts reported in some burned forests, where numbers also decline after 2- 
4603 years (Murphy and Lenhhausen 1998, Hobson and Schieck 1999). In burned areas, increased

461 density of these woodpeckers is attributed to increased food resources of insects on and in fire-

462 killed trees (Rota et al. 2015, Hannon and Drapeau 2005). We suspect that selection logging,

463 which produces large amounts of residual wood left on the forest floor, piles of untransported

464 logs, and trees damaged from the logging operations, results in an increase in boring insects

465 similar to burning, and attracts black-backed woodpeckers from surrounding forests.

466 Nevertheless, burned and selection logged forests are only a temporary supply of high value

467 food patches that do not last much longer than 3 years (Hannon and Drapeau 2005, Nappi et al.

468 2009). Therefore, while burned and partly-logged forests may act as sources (Nappi et al. 2009),

469 old and mature forests must act a as reservoirs for this species, where although breeding

470 densities are low, large numbers of birds exist across large landscapes making it important to

471 maintain large blocks of mature and older forests for black-backed woodpecker populations.

472 We were surprised that winter occurrence predicted spring breeding counts for five of

473 seven resident species because a winter population includes non-breeding birds and juveniles,

474 as well as adults from the previous spring. We are aware of only of two other studies that

475 compared winter to breeding densities of resident birds from an area with snow and cold

476 temperatures. Desrochers et al. (1999) found lower breeding densities of black-capped

477 chickadees than occurred in winter. In our area, black-caped chickadees appeared to use

478 mature pine in winter at higher densities than in summer, suggesting that these stands may be

479 important wintering habitats. Koivula and Schmiegelow (2007) found no correlation between

480 winter abundance and breeding season abundance of black-backed woodpeckers in unlogged

481 stands but comparable numbers in various logged stands, in Alberta. Our results were similar 
482 but only for the unmanaged mature pine stands, with no differences in either other stand types

483 from winter to summer. Similar to chickadees, this woodpecker species used mature pine

484 mixedwood stands in these transition forests as important wintering habitat.

485 Short-term data does not enable assessment of how communities may change over

486 time and most studies of breeding birds are conducted only over a short time of 2 or 3 seasons.

487 Our longer term data enabled us to assess inter-year variance of relative abundance by species

488 among habitats. The general lack of difference in abundances across years among our

489 unharvested stand types suggested stable community structure and habitat selection by all of

490 our resident and woodpecker breeding species, and for all residents except black-capped

491 chickadees. Kampichler et al. (2014) also detected long-term stable community structure

492 among most breeding birds using datasets from several different ecosystems that had little or

493 no anthropogenic disturbance. Our black-capped chickadees were likely responding to

494 availability of winter foods, similar to a few species in the Kampichler et al. (2014) study that

495 responded numerically to irruptive insect larvae.

496 Somewhat contrary to the results of Kirk et al. (2012), our data suggested that old

497 growth pine did not support a particular resident or cavity-nesting community. Nevertheless, it

498 was clear from our results that large pine trees are an important resource for many species

499 both as foraging and nesting substrates. Unfortunately, in many areas of eastern Canada, these

500 trees were harvested without replacement decades ago (Thompson et al. 2006, Kirk et al.

501 2012). We suggest that, regardless of age, stands with a large proportion of pine trees of $d b h$

$502>40 \mathrm{~cm}$ provide important habitats for resident and cavity-nesting birds in mixedwood forests 
503 and that maintaining landscapes with a high proportion of large conifer trees may be essential 504 for black-backed woodpecker populations.

505

\section{Acknowledgements}

507

508 This study was initiated and funded for the first 2 years under the Ontario Ministry of Natural

509 Resources, Landscape Ecology Program through A. Perera of the Ontario Forest Research

510 Institute. We thank J.A. Baker and D.A. Welsh who assisted with the study design and also

511 thank the several observers who participated over the 11 years, including: D. Ortiz, D. Oliver, K.

512 Mcllwrick, M. O’Connor, C. Jastrebski, S. Dobbyn, R. Russell, E. Wianko, K. Falk, R. Knudsen, D.

513 Wiese, P. Mikoda, and C. Sanders. In particular, D. Ortiz, D. Oliver and C. Jastrebski observed in

514 most years. L. Nituch assisted with some analyses. 


\section{References}

Adams, E.M., and Morrison, M.L. 1993. Effects of forest stand structure and composition on red-breasted nuthatches and brown creepers. J. Wildl. Manage. 57: 616-629.

Aird, P.L. 1985. In praise of pine: the eastern white pine and red pine timber harvest from Ontario's Crown forest. Canadian Forest Service Report No. PI-X-52, Petawawa, ON.

Anderson, M.J., Clarke, K.R., and Gorley, R.N. 2008. PERMANOVA + for Primer v6: User manual/tutorial. Primer-E, Plymouth, UK.

Barton, K. 2015. MuMIn: Multi-Model Inference. R package version 1.15.1. http://CRAN.Rproject.org/package=MuMIn

Bates, D., Maechler, M., Bolker, B., and Walker, S. 2015. Ime4: Linear mixed-effects models using Eigen and S4. R package version 1.1-8, http://CRAN.R-project.org/package=Ime4.

Blaser, J., Sarre, A., Poore, D., and Johnson, S. 2011. Status of Tropical Forest Management 2011. ITTO Technical Series No 38. International Tropical Timber Organization, Yokohama, Japan.

Brush, T. 1983. Cavity use by secondary cavity-nesting birds and response to manipulations. Condor 85: 461-466. 
Carleton, T. J. 2003. Old growth in the Great Lakes forest. Environ. Rev. 11: S115-S134.

Clarke, K.R., and Gorley, R.N. 2001. Primer v5: User manual/tutorial. Primer-E, Plymouth, UK.

Davis, C.M. 1978. A nesting study of the brown creeper. Living Bird 17: 237-263.

Desrochers, A., Hannon, S.J., and Nordin, K.E. 1988. Winter survival and territory acquisition in a northern population of Black-capped Chickadees. The Auk 105: 727-736.

Drapeau, P., A. Leduc, J.-F Giroux, J.-P. Savard, Y. Bergeron, and W.L. Vickery. 2000. Landscape scale disturbances and changes in bird communities of boreal mixed-wood forests. Ecol.

Monogr. 70: 423-444.

Franzreb, K.E. 1985. Foraging ecology of brown creepers in a mixed-coniferous forest. Journal of Field Ornithology 56: 9-16.

Godfrey, W.E. 1990. The birds of Canada. National Museum of Natural Sciences, National Museums of Canada, Ottawa.

Hejl, S.J., Newlon, K.R., McFadzen, M.E., Young, J.S., and Ghalambor, C.K. 2002. Brown creeper (Certhia americana) In The birds of North America online. Edited by A. Poole. Cornell 
Laboratory of Ornithology, Ithaca, NY. Available online at:

http://bna.birds.cornell.edu/bna/species/669/articles/introduction (accessed Nov. 23, 2015)

Holmes, R.T., and Robinson, S.K. 1988. Tree species preferences of foraging insectivorous birds in a northern hardwoods forest. Oecologica 48: 31-35.

Hothorn, T., F. Bretz and P. Westfall. 2008. Simultaneous inference in general parametric models. Biometr. J. 50: 346--363.

Hout, J.S., and Hannon, S.J. 2002. Habitat associations of black-backed and three-toed woodpeckers in the boreal forest of Alberta. Can. J. For. Res. 32: 1881-1888.

Kampichler, C., Angeler, D.G., Holmes, R.T., Leito, A., Svensson, S., van der Jeugd, H.P., and Wesołowski , T. 2014. Temporal dynamics of bird community composition: an analysis of baseline conditions from long-term data. Oecologia 175: 1301-1313.

Kennard, J.H. 1976. A biennial rhythm in the winter distribution of the Common Redpoll. BirdBanding 47: 231-237.

Kirk, D.A., Welsh, D.A., Baker, J.A., Thompson, I.D., and Csizy, M. 2012. Avian assemblages differ between old-growth and mature white pine forests of Ontario: a role for super-canopy pine? Avian Conserv. Ecol. 7: art. 4 http://www.ace-eco.org/vol7/iss1/. 
Koenig, W.D., and Knops, J.M.H. 2001. Seed-crop size and eruptions of North American boreal seed-eating birds. J. Anim. Ecol. 70: 609-620.

Mariani, J.M., and Manuwal, D.A. 1990. Factors influencing brown creeper abundance patterns in the southern Washington cascade range. Stud. Avian Biol. 13: 53-57.

Martin, A.C., Zim, H.S., and Nelson, A.L. 1951. American wildlife and plants: A guide to wildlife food habits. Dover, New York.

Mosseler, A., Thompson, I., and B.A. Pendrel, B.A. 2003. Overview of old-growth forests in Canada from a science perspective. Environ. Rev. 11: S1-S7.

Murphy, E.C., and Lenhhausen, W.A. 1998. Density and foraging ecology of woodpeckers following a stand-replacement fire. J. Wildl. Manage. 62: 1359-1372.

Nappi, A., and Drapeau, P. 2009. Reproductive success of the black-backed woodpecker (Picoides arcticus) in burned boreal forests: Are burns source habitats? Biol. Conserv. 142: 1381-1391.

Ontario MNRF (Ministry of natural Resources and Forests). 2015. State of Ontario's forests. http://www.ontario.ca/document/state-ontarios-forests accessed: 5 October 2015. 
Poulin, J.F., Villard, M.-A., Edman, M., Goulet, P.J., and Eriksson, A.M. 2008. Thresholds in nesting habitat requirements of an old forest specialist, the Brown Creeper (Certhia americana), as conservation targets. Biol. Conserv. 141: 1129-1137.

R Core Team. 2015. R: A language and environment for statistical computing. R Foundation for Statistical Computing, Vienna, Austria. URL http://www.R-project.org/.

Rowe, J.S. 1972. The forest regions of Canada. Canadian Forest Service Publication No. 1300. Ottawa.

Smirnova, E., Bergeron, Y., and Brais, S. 2008. Influence of fire intensity on structure and composition of jack pine stands in the boreal forest of Quebec: live trees, understory vegetation and dead wood dynamics. For. Ecol. Manage. 255: 2916-2927.

Thomas, J.W., Ruggiero, L.F., Mannan, R.W., Schoen, J.W., and Lancia, R.A. 1988. Management and conservation of old-growth forests in the United States. Wildl. Soc. Bull. 16: 252-262.

Thompson, F.R., and Capen, D.E. 1988. Avian assemblages in seral stages of a Vermont forest. J. Wildl. Manage. 52: 771-777. 
Thompson, I.D., Kirk, D.A., and Jastrebski, C. 2013. Does post-harvest silviculture improve convergence of avian communities in managed forests with those using old growth boreal forests? Can. J. For. Res. 43: 1050-1062.

Thompson, I.D., Simard, J., and Titman, R. 2006. Historical changes in the density of white pine in Algonquin Park, Ontario, Canada in the $19^{\text {th }}$ century. Natur. Areas J. 26: 61-71.

Vaillancourt, M.-A., Drapeau, P., Gauthier, S., and Robert, M. 2008. Availability of standing trees for large cavity-nesting birds in the eastern boreal forest of Quebec, Canada. For. Ecol. Manage. 255: 2272-2285.

Venier, L.A., Thompson, I.D., Fleming, R., Malcolm, J., Aubin, I., Trofymow, J.A., Langor, D., Sturrock, R., Patry, C., Outerbridge, R.O., Holmes, S.B., Haeussler, S., De Grandpré, L., Bayne, E., Arsenault, A., and Brandt, J.P. 2014. Effects of natural resource development on the terrestrial biodiversity of Canadian boreal forests. Envir. Rev. 22: 457-490.

Welsh, D.A., Clark, T., and Clark, K. 1992. Fauna of red and white pine old-growth forests in Ontario: issues and recommendations for research. Ont. Min. Nat. Res., Ont. For. Res. Inst. Forest Fragmentation and Biodiversity Proj., Rept. No. 3. Sault Ste. Marie, Ont.

Wood, S.N. 2011. Fast stable restricted maximum likelihood and marginal likelihood estimation of semiparametric generalized linear models. Journal of the Royal Statistical Society (B) 73:3-36. 
Wray, D. 1986. Managing white pine in Ontario. In Eastern white pine: today and tomorrow. Edited by D.T. Funk. Gen. Tech. Rept. WO-51, U.S. Dept. Agric., For. Serv., Durham, New Hampshire, USA. pp. 67-69. 
Figure captions:

Figure 1. Mean abundance (SE) of the five most common resident birds in winter in the Spanish Forest on 0.5 $\mathrm{km}^{2}$ plots by stand types, from 1995 to 2005.

Figure 2. Mean annual winter counts of five nomadic species in winter in the Spanish Forest on $0.5 \mathrm{~km}^{2}$ plots by stand types, from 1995 to 2005.

Figure 3. Number of breeding woodpecker pairs by species among years and stand types on $0.25 \mathrm{~km}^{2}$ plots in the Spanish forest by stand types, from 1999 to 2007.

Figure 4. Number of breeding pairs of secondary cavity-nesters in the Spanish forest on $0.25 \mathrm{~km}^{2}$ plots by stand types, from 1999 to 2007. 
Table 1. Model averaging results for resident birds in winter in the Lower Spanish Forest, Ontario, from 1995 to 2005. Mixedwood stand types were: old growth pine (>150 yrs), mature pine, and mature non-pine. Importance value is the sum of $\mathrm{AIC}_{\mathrm{c}}$ weight scores for the models in the $95 \%$ confidence set that included the row variable.

\begin{tabular}{|c|c|c|c|c|c|c|c|c|}
\hline Response & $\begin{array}{l}\text { Stand } \\
\text { type }\end{array}$ & $\begin{array}{l}\text { Stand type } \\
\text { importance }\end{array}$ & $\%$ Pine & $\begin{array}{l}\text { \% Pine } \\
\text { importance }\end{array}$ & $\begin{array}{l}\text { Basal area } \\
\mathrm{m}^{2} \mathrm{ha}^{-1}\end{array}$ & $\begin{array}{l}\text { Basal area } \\
\text { importance }\end{array}$ & Snags & $\begin{array}{l}\text { Snags } \\
\text { importance }\end{array}$ \\
\hline Species Richness & NS & 0.19 & NS & 0.25 & NS & 0.22 & $*,-$ & 0.85 \\
\hline Simpson's index & NS & 0.53 & NS & 0.39 & NS & 0.26 & $*,-$ & 0.78 \\
\hline Strong cavity excavators & NS & 0.17 & NS & 0.29 & NS & 0.31 & NS & 0.35 \\
\hline Weak cavity excavators & $* * *$ & 1.00 & NS & 0.10 & $*,+$ & 0.70 & $* *,-$ & 1.00 \\
\hline Secondary cavity users & NS & 0.27 & NS & 0.50 & NS & 0.27 & NS & 0.24 \\
\hline Residents & $* * *$ & 0.86 & $* * *,+$ & 0.14 & $* *,+$ & 1.00 & $* * *,-$ & 1.00 \\
\hline Nomads & NS & 0.13 & $*,+$ & 0.95 & NS & 0.29 & NS & 0.24 \\
\hline Downy woodpecker & NS & 0.05 & NS & 0.27 & NS & 0.41 & NS & 0.58 \\
\hline Hairy woodpecker & NS & 0.26 & NS & 0.22 & NS & 0.24 & NS & 0.43 \\
\hline Pileated woodpecker & NS & 0.22 & NS & 0.24 & NS & 0.28 & NS & 0.24 \\
\hline Black-backed woodpecker & NS & 0.15 & $*,+$ & 0.82 & $*,-$ & 0.93 & NS & 0.22 \\
\hline Red-breasted nuthatch & $* * *$ & 1.00 & NS & 0.29 & $*,+$ & 0.90 & NS & 0.17 \\
\hline Black-capped chickadee & $* * *$ & 0.84 & NS & 0.35 & NS & 0.27 & $* *,-$ & 1.00 \\
\hline Boreal chickadee & NS & 0.12 & $*,-$ & 0.84 & NS & 0.31 & NS & 0.53 \\
\hline Gray jay & $* *$ & 0.97 & NS & 0.28 & NS & 0.31 & NS & 0.36 \\
\hline Blue jay & $*$ & 0.85 & NS & 0.31 & NS & 0.28 & NS & 0.36 \\
\hline White-winged crossbill & $* *$ & 0.96 & $* * *,+$ & 1.00 & $*,+$ & 0.70 & NS & 0.14 \\
\hline Common redpoll & NS & 0.17 &.,- & 0.77 & NS & 0.47 & NS & 0.54 \\
\hline Pine siskin & $* *$ & 0.96 & NS & 0.15 & $*,-$ & 0.67 & $* *,+$ & 0.97 \\
\hline Pine grosbeak & NS & 0.19 & NS & 0.32 & $*,-$ & 0.89 & NS & 0.31 \\
\hline Ruffed grouse & NS & 0.11 & NS & 0.24 & $*,+$ & 0.87 & NS & 0.44 \\
\hline
\end{tabular}


Table 2. Significant differences among stand types used in winter and spring by resident and cavity-nesting birds in the Spanish Forest. Stand rankings were determined by Tukey tests for groups or species where the GLMM indicated a 'stand type' effect. Stands are ranked from ' $a$ ' most used, to ' $c$ ' least used and stands with the same letter were used equally $(P<0.05)$. (Harvested stands were not surveyed in winter.)

\begin{tabular}{|c|c|c|c|c|}
\hline $\begin{array}{l}\text { Season/ } \\
\text { Species or guild }\end{array}$ & $\begin{array}{l}\text { Old growth } \\
\text { pine }\end{array}$ & $\begin{array}{l}\text { Mature } \\
\text { pine }\end{array}$ & $\begin{array}{l}\text { Non-pine } \\
\text { mixedwood }\end{array}$ & $\begin{array}{l}\text { Selection } \\
\text { harvested }\end{array}$ \\
\hline \multicolumn{5}{|l|}{ Winter } \\
\hline Species Richness & $\mathrm{a}$ & $\mathrm{a}$ & $\mathrm{a}$ & \\
\hline Simpson's index & $\mathrm{a}$ & $\mathrm{a}$ & $\mathrm{a}$ & \\
\hline Strong cavity excavators & $\mathrm{a}$ & $\mathrm{a}$ & $\mathrm{a}$ & \\
\hline Weak cavity excavators & $\mathrm{a}$ & $\mathrm{a}$ & $\mathrm{b}$ & \\
\hline Residents & $\mathrm{a}$ & $\mathrm{a}$ & $\mathrm{b}$ & \\
\hline Nomads & $\mathrm{a}$ & $\mathrm{a}$ & $\mathrm{a}$ & \\
\hline Downy woodpecker & $\mathrm{a}$ & $\mathrm{a}$ & $\mathrm{a}$ & \\
\hline Hairy woodpecker & $\mathrm{a}$ & $\mathrm{a}$ & $\mathrm{a}$ & \\
\hline Pileated woodpecker & $\mathrm{a}$ & $\mathrm{a}$ & $\mathrm{a}$ & \\
\hline Black-backed woodpecker & $\mathrm{a}$ & $\mathrm{a}$ & $\mathrm{a}$ & \\
\hline Red-breasted nuthatch & $\mathrm{a}$ & $\mathrm{a}$ & $\mathrm{b}$ & \\
\hline Black-capped chickadee & $\mathrm{a}$ & $\mathrm{a}$ & $\mathrm{b}$ & \\
\hline Boreal chickadee & $\mathrm{a}$ & $\mathrm{a}$ & $\mathrm{a}$ & \\
\hline Gray jay & $\mathrm{b}$ & $\mathrm{ab}$ & $\mathrm{a}$ & \\
\hline Blue jay & $\mathrm{a}$ & $\mathrm{a}$ & $\mathrm{a}$ & \\
\hline White-winged crossbill & $\mathrm{a}$ & $\mathrm{a}$ & $\mathrm{a}$ & \\
\hline Common redpoll & $\mathrm{a}$ & $\mathrm{a}$ & $\mathrm{a}$ & \\
\hline Pine siskin & $\mathrm{a}$ & $\mathrm{a}$ & $\mathrm{b}$ & \\
\hline Pine grosbeak & $\mathrm{a}$ & $\mathrm{a}$ & $\mathrm{a}$ & \\
\hline Ruffed grouse & $\mathrm{a}$ & $\mathrm{a}$ & $\mathrm{a}$ & \\
\hline \multicolumn{5}{|l|}{ Spring } \\
\hline Species Richness & $\mathrm{a}$ & $\mathrm{a}$ & $\mathrm{a}$ & $\mathrm{a}$ \\
\hline Simpson's index & $\mathrm{a}$ & $\mathrm{a}$ & $\mathrm{a}$ & $\mathrm{a}$ \\
\hline Strong cavity excavators & $\mathrm{b}$ & $\mathrm{b}$ & $\mathrm{b}$ & $\mathrm{a}$ \\
\hline Weak cavity excavators & $\mathrm{a}$ & $\mathrm{a}$ & $\mathrm{a}$ & $\mathrm{a}$ \\
\hline Residents & $\mathrm{a}$ & $\mathrm{a}$ & $\mathrm{a}$ & $\mathrm{a}$ \\
\hline Non-residents & $\mathrm{b}$ & $\mathrm{ab}$ & $\mathrm{ab}$ & $\mathrm{a}$ \\
\hline Downy woodpecker & $\mathrm{a}$ & $\mathrm{a}$ & $\mathrm{a}$ & $\mathrm{a}$ \\
\hline Hairy woodpeckers & $\mathrm{b}$ & $\mathrm{ab}$ & $\mathrm{ab}$ & $\mathrm{a}$ \\
\hline Pileated woodpecker & $\mathrm{a}$ & $\mathrm{a}$ & $\mathrm{a}$ & $\mathrm{a}$ \\
\hline Yellow-bellied sapsucker & $\mathrm{b}$ & $\mathrm{bc}$ & $\mathrm{c}$ & $\mathrm{a}$ \\
\hline Common flicker & $\mathrm{b}$ & $\mathrm{ab}$ & $\mathrm{ab}$ & $\mathrm{a}$ \\
\hline Black-backed woodpecker & $\mathrm{a}$ & $\mathrm{a}$ & $\mathrm{a}$ & $\mathrm{a}$ \\
\hline Red-breasted nuthatch & $\mathrm{a}$ & $\mathrm{a}$ & $\mathrm{a}$ & $\mathrm{a}$ \\
\hline Black-capped chickadee & $\mathrm{ab}$ & $\mathrm{a}$ & $\mathrm{ab}$ & $\mathrm{b}$ \\
\hline Brown creeper & $\mathrm{a}$ & $\mathrm{a}$ & $\mathrm{a}$ & $\mathrm{b}$ \\
\hline
\end{tabular}


Table 3. Model averaging results for breeding cavity-nesting bird species in the Lower Spanish Forest, Ontario from 1999 to 2007. Mixedwood

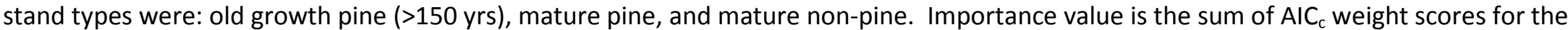
models in the $95 \%$ confidence set that included the row variable.

\begin{tabular}{|c|c|c|c|c|c|c|c|c|}
\hline Response & $\begin{array}{l}\text { Stand } \\
\text { type }\end{array}$ & $\begin{array}{l}\text { Stand type } \\
\text { importance }\end{array}$ & \% Pine & $\begin{array}{l}\text { \% Pine } \\
\text { importance }\end{array}$ & $\begin{array}{l}\text { Basal area } \\
\mathrm{m}^{2} \mathrm{ha}^{-1}\end{array}$ & $\begin{array}{l}\text { Basal area } \\
\text { importance }\end{array}$ & Snags & $\begin{array}{l}\text { Snag } \\
\text { importance }\end{array}$ \\
\hline Species Richness & NS & 0.02 & NS & 0.26 & NS & 0.25 & NS & 0.24 \\
\hline Simpson's index & NS & 0.05 & NS & 0.28 & NS & 0.37 & NS & 0.29 \\
\hline Strong cavity excavators & $* *$ & 1.00 & $*,-$ & 0.81 & NS & 0.17 & NS & 0.22 \\
\hline Weak cavity excavators & NS & 0.22 & NS & 0.25 &.,+ & 0.69 & NS & 0.27 \\
\hline Residents & NS & 0.11 & NS & 0.60 & NS & 0.53 & NS & 0.24 \\
\hline Non-residents & $*$ & 0.75 & NS & 0.49 & NS & 0.40 & NS & 0.46 \\
\hline Downy woodpecker & NS & 0.30 & NS & 0.33 & NS & 0.78 & NS & 0.31 \\
\hline Hairy woodpecker & . & 1.00 & NS & 0.32 & NS & 0.40 & NS & 0.25 \\
\hline Yellow-bellied sapsucker & $* * *$ & 1.00 & $* *,-$ & 0.98 & NS & 0.06 & $*,+$ & 0.75 \\
\hline Pileated woodpecker & NS & 0.00 & NS & 0.26 & NS & 0.25 &.,- & 0.60 \\
\hline Common flicker & $*$ & 0.47 & NS & 0.51 & NS & 0.29 & NS & 0.48 \\
\hline Black-backed woodpecker & $*$ & 0.68 &.,+ & 1.00 & NS & 0.34 & NS & 0.21 \\
\hline Red-breasted Nuthatch & NS & 0.33 & NS & 0.32 & NS & 0.29 & NS & 0.35 \\
\hline Black-capped Chickadee & . & 0.63 & NS & 0.53 & NS & 0.29 & NS & 0.41 \\
\hline Brown creeper & $* * *$ & 1.00 & $* * *,+$ & 1.00 & NS & 0.56 & NS & 0.00 \\
\hline
\end{tabular}

Significance levels: $* * *=<0.0001, * *<0.001, *=<0.05, .=<0.1$, NS = not significant $;+$ or $-=$ direction of effect 
Table 4. AIC values for a year $\mathrm{x}$ habitat interaction, in a model of species counts in habitat by year. For species acronyms see Appendix 1.

\begin{tabular}{|l|l|l|l|l|l|l|l|l|l|l|l|l|l|l|l|}
\hline & & & & & & & Species & & & & & & & \\
\hline Season & Year treatment & BCCH & RBNU & DOWO & WWCR & CORE & PISI & GRJA & CORA & BOCH & HAWO & BRCR & YBSS & COFL & PIWO \\
\hline Winter & random & 0.000 & 0.000 & 0.001 & 0.000 & 0.000 & 0.000 & 0.977 & 0.270 & 0.670 & 0.998 & 0.998 & NA & NA & NA \\
\hline & fixed intercept & 0.000 & 1.000 & 0.999 & 1.000 & 0.972 & 1.000 & 0.024 & 0.730 & 0.330 & 0.002 & 0.002 & NA & NA & NA \\
\hline & interaction & 1.000 & 0.000 & 0.000 & 0.000 & 0.028 & 0.000 & 0.000 & 0.000 & 0.000 & 0.000 & 0.000 & NA & NA & NA \\
\hline Spring & random & 0.000 & 0.021 & 0.181 & NA & NA & NA & NA & NA & NA & 0.927 & 0.006 & 0.382 & 0.371 & 0.200 \\
\hline & fixed intercept & 0.999 & 0.976 & 0.819 & NA & NA & NA & NA & NA & NA & 0.073 & 0.994 & 0.618 & 0.629 & 0.801 \\
\hline & interaction & 0.001 & 0.003 & 0.000 & NA & NA & NA & NA & NA & NA & 0.000 & 0.000 & 0.000 & 0.000 & 0.000 \\
\hline
\end{tabular}


Figure 1
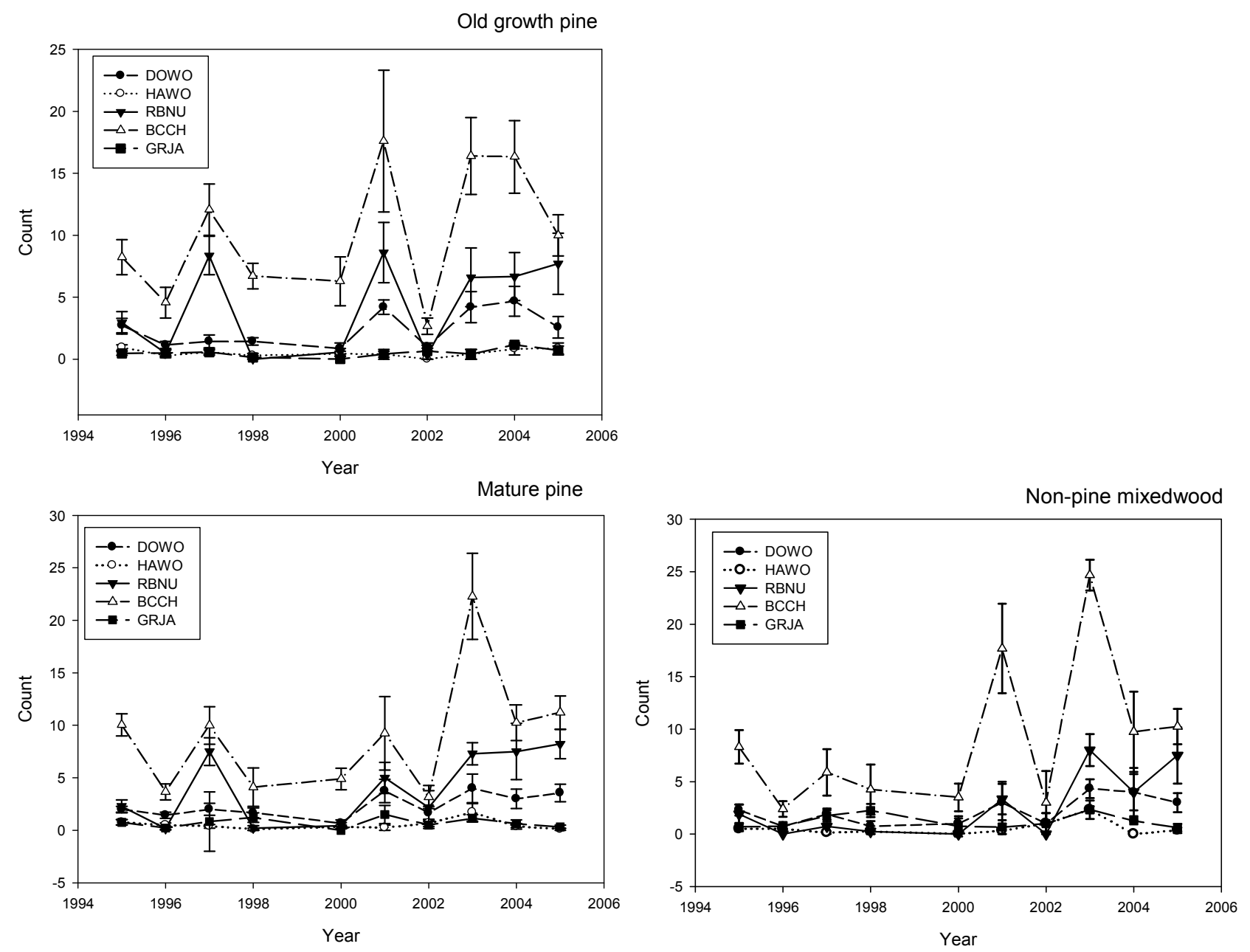
Figure 2
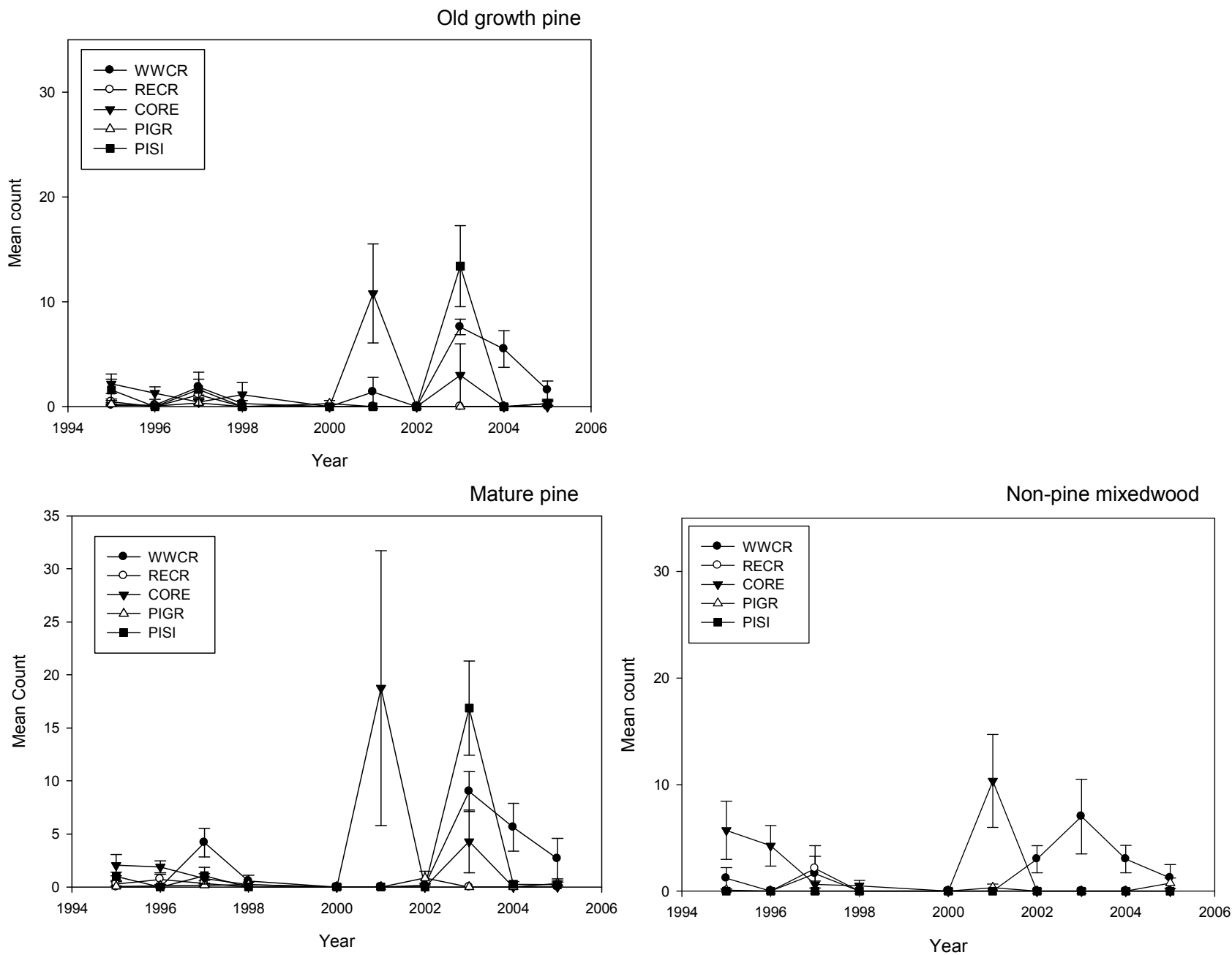
Figure 3
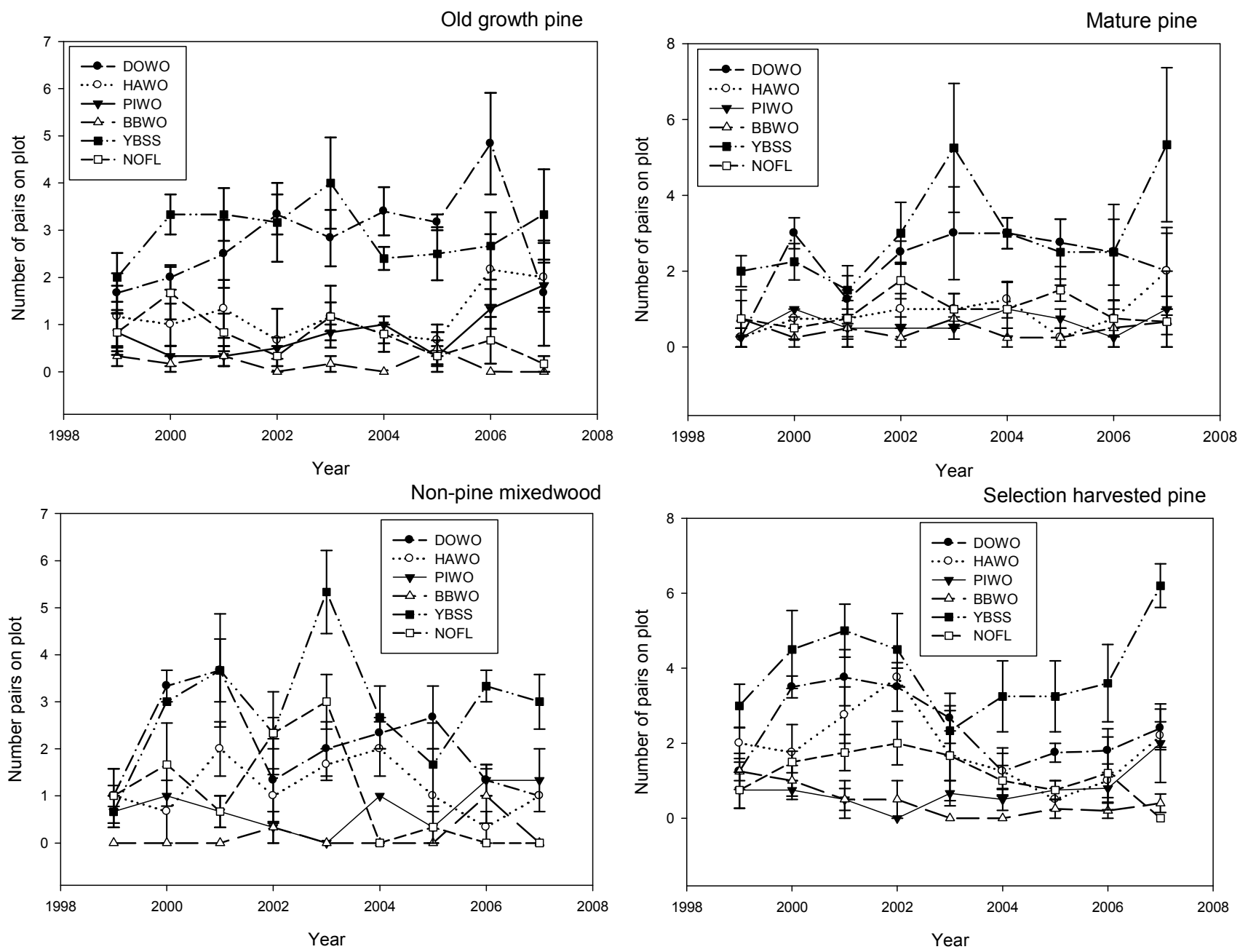
Figure 4
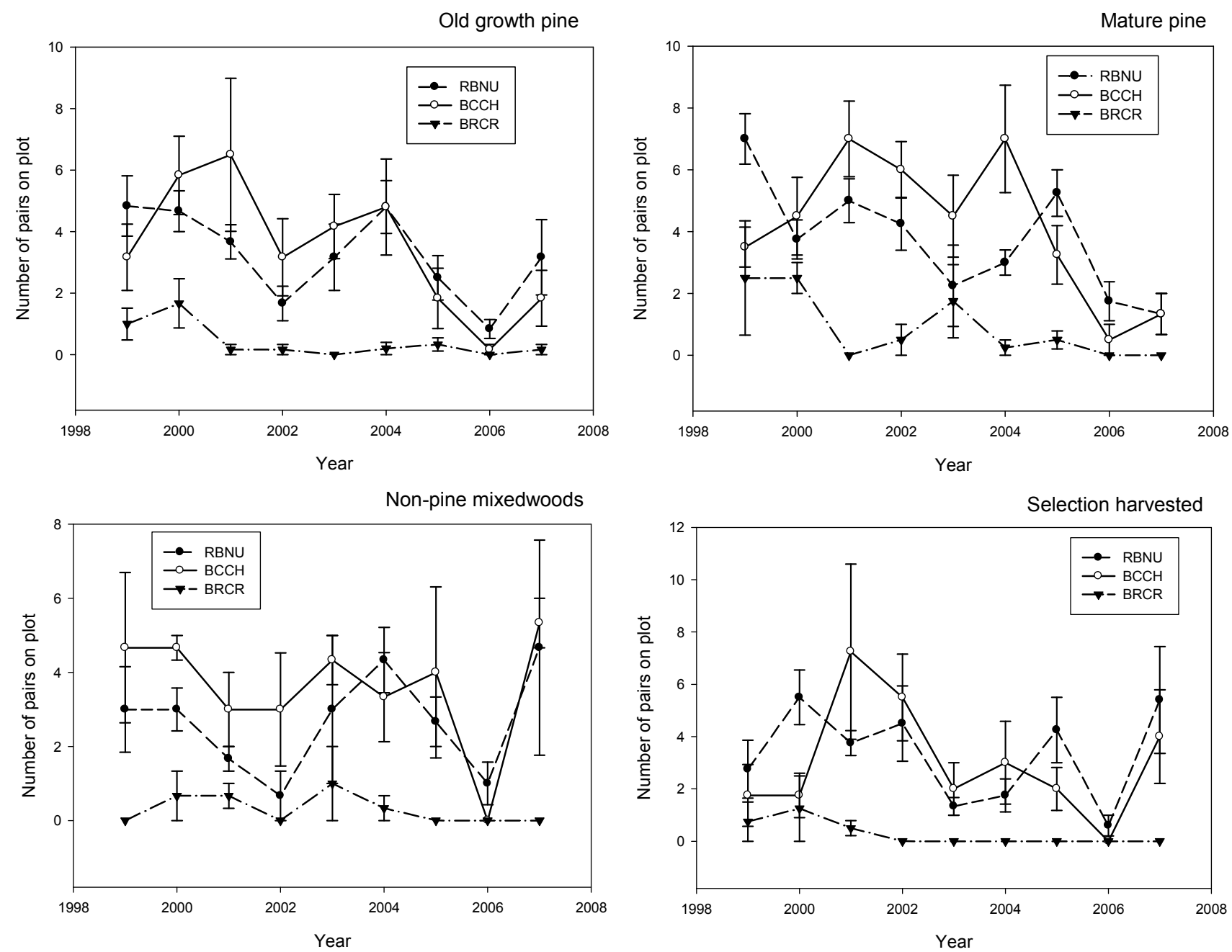
Appendix 1. Common and scientific names of birds recorded in winter or spring and their guild assignments.

\begin{tabular}{|c|c|c|c|}
\hline Acronym & Common Name (Scientific name) & Cavity guild & Migratory Status \\
\hline AMGO & American Goldfinch Spinus tristis & & Short-distance migrant \\
\hline BBWO & Black-backed Woodpecker Picoides arcticus & Strong primary & Resident \\
\hline $\mathrm{BCCH}$ & Black-capped Chickadee Poecile atricapillus & Weak primary & Resident \\
\hline BLJA & Blue Jay Cyanocitta cristata & & Short-distance (resident) \\
\hline $\mathrm{BOCH}$ & Boreal Chickadee Poecile hudsonicus & Weak primary & Resident \\
\hline BOOW & Boreal Owl Aegolius funereus & Secondary & Resident \\
\hline BRCR & Brown Creeper Certhia americana & Secondary & Short-distance \\
\hline CORA & Common Raven Corvus corax & & Resident \\
\hline CORE & Common Redpoll Acanthis flammea & & Nomad (resident) \\
\hline DOWO & Downy Woodpecker Picoides pubescens & Weak primary & Resident \\
\hline GCKI & Golden-crowned Kinglet Regulus satrapa & ? & Short-distance (resident) \\
\hline GRAJ & Gray Jay Perisoreus canadensis & & Resident \\
\hline HAWO & Hairy Woodpecker Picoides villosus & Strong primary & Resident \\
\hline NOFL & Northern Flicker Colaptes auratus & Strong primary & Short-distance migrant \\
\hline PIGR & Pine Grosbeak Pinicola enucleator & & Nomad (resident) \\
\hline PISI & Pine Siskin Spinus pinus & & Nomad (short-distance) \\
\hline PIWO & Pileated Woodpecker Dryocopus pileatus & Strong primary & Resident \\
\hline PUFI & Purple Finch Carpodacus purpureus & & Short-distance (resident) \\
\hline RBNU & Red-breasted Nuthatch Sitta canadensis & Weak primary & Resident (nomadic) \\
\hline RECR & Red Crossbill Loxia curvirostra & & Nomad \\
\hline RUGR & Ruffed Grouse Bonasa umbellus & & Resident \\
\hline
\end{tabular}




\begin{tabular}{|l|l|l|l|}
\hline SPGR & Spruce Grouse Falcipennis canadensis & & Resident \\
\hline TTWO & American Three-toed Woodpecker Picoides dorsalis & Strong primary & Resident \\
\hline WBNU & White-breasted Nuthatch Sitta carolinensis & Weak primary & Resident \\
\hline WWCR & White-winged Crossbill Loxia leucoptera & & Nomad (resident) \\
\hline YBSS & Yellow-bellied Sapsucker Sphyrapicus varius & Strong primary & Short-distance migrant \\
\hline
\end{tabular}


Appendix 2. Mean counts of bird species in winter by stand types from 1995-2005. (One mature pine stand was converted to a selection harvested stand in 2003.)

\begin{tabular}{|c|c|c|c|c|c|c|c|c|}
\hline & $\begin{array}{l}\text { Non-pi } \\
(\mathrm{n}=4)\end{array}$ & nixed wood & $\begin{array}{l}\text { Matur } \\
(\mathrm{n}=7,\end{array}$ & & $\begin{array}{l}\text { Old-g } \\
(\mathrm{n}=6\end{array}$ & pine & $\begin{array}{l}\text { Select } \\
(\mathrm{n}=2\end{array}$ & irvested \\
\hline Species & Mean & SE & Mean & $\mathrm{SE}$ & Mean & SE & Mean & $\mathrm{SE}$ \\
\hline $\begin{array}{l}\text { Downy } \\
\text { woodpecker }\end{array}$ & 2.10 & 0.29 & 2.22 & $\begin{array}{l}0.2359 \\
03 \\
\end{array}$ & 2.13 & 0.20 & 1.33 & 0.88 \\
\hline $\begin{array}{l}\text { Hairy } \\
\text { woodpecker }\end{array}$ & 0.46 & 0.12 & 0.56 & 0.08 & 0.52 & 0.09 & 0 & 0 \\
\hline $\begin{array}{l}\text { Pileated } \\
\text { woodpecker }\end{array}$ & 0.27 & 0.09 & 0.20 & 0.05 & 0.09 & 0.03 & 0 & 0 \\
\hline $\begin{array}{l}\text { Black-backed } \\
\text { woodpecker }\end{array}$ & 0.23 & 0.08 & 0.10 & 0.03 & 0.18 & 0.05 & 0.33 & 0.33 \\
\hline $\begin{array}{l}\text { Northern three- } \\
\text { toed } \\
\text { woodpecker }\end{array}$ & 0.02 & 0.02 & 0.01 & 0.01 & 0.01 & 0.01 & 0 & 0 \\
\hline $\begin{array}{l}\text { Red-breasted } \\
\text { nuthatch }\end{array}$ & 1.98 & 0.47 & 4.14 & 0.55 & 3.74 & 0.46 & 6.67 & 4.41 \\
\hline $\begin{array}{l}\text { White-breasted } \\
\text { nuthatch }\end{array}$ & 0 & 0 & 0.01 & 0.01 & 0.02 & 0.01 & 0 & 0 \\
\hline $\begin{array}{l}\text { Black-capped } \\
\text { chickadee }\end{array}$ & 7.43 & 1.07 & 9.46 & 0.80 & 8.52 & 0.68 & 10.67 & 2.73 \\
\hline $\begin{array}{l}\text { Boreal } \\
\text { chickadee }\end{array}$ & 0.96 & 0.27 & 0.55 & 0.12 & 0.52 & 0.12 & 0 & 0 \\
\hline Blue jay & 0.35 & 0.11 & 0.44 & 0.08 & 0.34 & 0.07 & 0 & 0 \\
\hline Gray jay & 1.08 & 0.17 & 0.57 & 0.10 & 0.68 & 0.10 & 0.67 & 0.67 \\
\hline Ruffed grouse & 0.33 & 0.09 & 0.57 & 0.11 & 0.37 & 0.08 & 0.33 & 0.33 \\
\hline Spruce grouse & 0.04 & 0.03 & 0.01 & 0.01 & 0.03 & 0.02 & 0 & 0 \\
\hline $\begin{array}{l}\text { White-winged } \\
\text { crossbill }\end{array}$ & 1.40 & 0.47 & 1.43 & 0.30 & 1.94 & 0.42 & 5.00 & 3.61 \\
\hline Red crossbill & 0.35 & 0.35 & 0.28 & 0.08 & 0.23 & 0.10 & 0 & 0 \\
\hline $\begin{array}{l}\text { Common } \\
\text { redpoll }\end{array}$ & 2.64 & 0.82 & 1.60 & 0.45 & 1.82 & 0.60 & 0 & 0 \\
\hline Brown creeper & 0.10 & 0.04 & 0.14 & 0.05 & 0.11 & 0.03 & 0 & 0 \\
\hline Pine grosbeak & 0.10 & 0.05 & 0.16 & 0.07 & 0.14 & 0.05 & 0.33 & 0.33 \\
\hline Pine siskin & 0.60 & 0.36 & 1.38 & 0.51 & 1.47 & 0.49 & 0 & 0 \\
\hline $\begin{array}{l}\text { American } \\
\text { goldfinch }\end{array}$ & 0.58 & 0.44 & 0 & 0 & 0 & 0 & 0 & 0 \\
\hline Purple finch & 0 & 0 & 0.01 & 0.01 & 0 & 0 & 0 & 0 \\
\hline $\begin{array}{l}\text { Golden- } \\
\text { crowned kinglet }\end{array}$ & 0.02 & 0.02 & 0.05 & 0.03 & 0.04 & 0.04 & 0 & 0 \\
\hline Boreal owl & 0 & 0 & 0 & 0 & 0.01 & 0.01 & 0 & 0 \\
\hline
\end{tabular}


Appendix 3. Mean counts (number of pairs) of breeding cavity-nesting bird species in spring by stand types from 1995-2005. (One mature pine stand was converted to a harvested stand in 2003.)

\begin{tabular}{|l|l|l|l|l|l|l|l|l|}
\hline & \multicolumn{2}{|l}{$\begin{array}{l}\text { Non-pine mixed wood } \\
(\mathrm{n}=4)\end{array}$} & \multicolumn{2}{l}{$\begin{array}{l}\text { Mature pine } \\
(\mathrm{n}=7,6)\end{array}$} & \multicolumn{2}{l}{$\begin{array}{l}\text { Old-growth pine } \\
(\mathrm{n}=6)\end{array}$} & \multicolumn{2}{l}{$\begin{array}{l}\text { Selection harvested } \\
(\mathrm{n}=4,5)\end{array}$} \\
\hline Species & Mean & SE & Mean & SE & Mean & SE & Mean & SE \\
\hline $\begin{array}{l}\text { Downy } \\
\text { Woodpecker }\end{array}$ & 2.07 & 0.24 & 2.26 & 0.26 & 2.81 & 0.24 & 2.40 & 0.22 \\
\hline $\begin{array}{l}\text { Hairy } \\
\text { woodpecker }\end{array}$ & 1.18 & 0.19 & 0.86 & 0.16 & 1.23 & 0.19 & 1.86 & 0.22 \\
\hline $\begin{array}{l}\text { Pileated } \\
\text { woodpecker }\end{array}$ & 0.74 & 0.13 & 0.63 & 0.11 & 0.81 & 0.11 & 0.78 & 0.18 \\
\hline $\begin{array}{l}\text { Black-backed } \\
\text { woodpecker }\end{array}$ & 0.15 & 0.09 & 0.46 & 0.12 & 0.17 & 0.06 & 0.46 & 0.11 \\
\hline $\begin{array}{l}\text { Red-breasted } \\
\text { nuthatch }\end{array}$ & 2.67 & 0.45 & 3.80 & 0.38 & 3.23 & 0.31 & 3.35 & 0.45 \\
\hline $\begin{array}{l}\text { Yellow-bellied } \\
\text { sapsucker }\end{array}$ & 2.85 & 0.31 & 2.97 & 0.37 & 2.98 & 0.23 & 4.05 & 0.32 \\
\hline $\begin{array}{l}\text { Black-capped } \\
\text { chickadee }\end{array}$ & 3.11 & 0.46 & 3.62 & 0.49 & 3.02 & 0.49 & 2.57 & 0.79 \\
\hline $\begin{array}{l}\text { Boreal } \\
\text { chickadee }\end{array}$ & 0.15 & 0.09 & 0.17 & 0.09 & 0.13 & 0.07 & 0.13 & 0.07 \\
\hline Brown creeper & 0.30 & 0.14 & 0.91 & 0.29 & 0.41 & 0.13 & 0.27 & 0.16 \\
\hline $\begin{array}{l}\text { Common } \\
\text { flicker }\end{array}$ & 1.00 & 0.24 & 0.97 & 0.16 & 0.75 & 0.14 & 1.13 & 0.19 \\
\hline
\end{tabular}

